\title{
SISTEM INFORMASI INVENTORY BARANG MENGGUNAKAN METODE WATERFALL
}

\author{
Sopian Aji ${ }^{1}$, Dany Pratmanto ${ }^{2}$ \\ Sistem Informasi, Universitas Nusa Mandiri \\ Email: ${ }^{1}$ sopian.sop@nusamandiri.ac.id, ${ }^{2}$ dany.dto@nusamandiri.ac.id
}

\begin{abstract}
Abstrak
Pencatatan inventory barang atau produk yakni pencatatan pengeluaran dan pemasukan, pencatatan pengeluaran merupakan transaksi atau pesanan barang sesuai dengan pesan supplier atau customer kemudian dicatatan oleh tugas gudang, sedangkan pencatatan pemasukan merupakan penambahan stok barang atau produk atau produk mentah yang dicatatan oleh tugas gudang. Pada inventory barang yang diteliti oleh penulis ini dimana proses pencatatan pengeluaran dan pemasukan barang yang dilakukan masih manual dengan masih menggunakan microsoft office excel karena karena aplikasi tersebut tidak bisa menyimpan data dan informasi secara terpusat pada suatu database. Untuk mengatasi permasalahan tersebut penulis menggunakan proses yang sebelumnya manual menjadi terkomputerisasi sehingga pencatatan pengeluaran dan pemasukan barang informasi yang dihasilkan lebih tepat dan akurat dengan data ditampilkan secara terpusat sehingga lebih efektif dan efisien. Dalam pengembangan sistem yaitu Software Development Life Cycle (SDLC) dengan metode Waterfall yang berorientasi objek dan berbasis web, perancangan Sistem menggunakan tools desain United Modelling languange (UML) dengan perancangan use case diagram, activity diagram dan sequence diagram, sedangkan perancangan database menggunakan tools desain Logical Record Structure (LRS).
\end{abstract}

Kata kunci: Sistem Informasi, Inventory Barang, Waterfall

\begin{abstract}
Recording inventory of goods or products, namely recording expenses and income, recording expenditures is a transaction or order of goods in accordance with the orders of suppliers or customers and then recorded by warehouse assignments, while recording entries is the addition of stock of goods or products or raw products recorded by warehouse assignments. In the inventory of goods studied by this author, the process of recording expenses and entry of goods is still manual using Microsoft Office Excel because the application cannot store data and information centrally in a database. To overcome this problem, the authors use a process that was previously manual to be computerized so that the recording of expenditures and entries of information items produced is more precise and accurate with data displayed centrally so that it is more effective and efficient. In system development, namely the Software Development Life Cycle (SDLC) with the object-oriented and web-based Waterfall method, the system design uses the United Modeling Language (UML) design tools with the design of use case diagrams, activity diagrams and sequence diagrams, while database design uses design tools Logical Record Structure (LRS).
\end{abstract}

Keywords: Information Systems, Inventory, Waterfall

\section{PENDAHULUAN}

Penerapan Inventory pada suatu perusahaan atau pelaku usaha berkaitan erat dengan kegiatan pengumpulan data tentang aktifitas serta transaksi masuk keluarnya barang atau produk dari suatu perusahaan atau pelaku usaha. Karena inventori begitu penting peranannya untuk perusahaan atau pelaku usaha, maka peranan suatu sistem inventori yang berbasis teknologi informasi (IT) sangatlah dibutuhkan untuk memudahkan pencatatan dan pengelolaan transaksi dari pada pencatatan dengan cara manual. Inventory atau biasa disebut dengan persediaan adalah simpanan barang atau produk mentah, material atau barang jadi yang disimpan untuk digunakan dalam masa mendatang atau dalam kurun waktu tertentu (Mufida et al., 2019). Persediaan merupakan sebagai suatu aktiva yang meliputi barang atau produk milik perusahaan yakni untuk dijual dalam suatu periode usaha yang normal, atau persediaan barang atau produk masih dalam pengerjaan/ proses produksi, atau adanya persediaan barang baku yang menunggu 
Indonesian Journal on Software Engineering (IJSE)

Vol. 7, No. 1, Juni 2021, hlm. 93-99

p-ISSN: 2461-0690

Akreditasi KEMENRISTEKDIKTI, No. 85/M/KPT/2020

e-ISSN: 2714-9935

penggunaannya dalam suatu proses produksi (Vikaliana et al., 2020). Sistem pengendalian atas persediaan yang baik maka akan menciptakan kondisi yang baik pada pelaku kegiatan usaha itu sendiri, tentu saja persediaan terjaga dengan baik. Sebaliknya jika sistem pengendalian atas persediaan tidak baik dan tidak sesuai, tentu saja mengakibatkan persediaan akan hilang sehingga menyebabkan perusahaan akan mengalami kerugian (Nugraha et al., 2018). Informasi yang biasanya didapatkan dengan cara yang tradisional atau manual, sudah tidak dapat digunakan lagi secara maksimal dalam memenuhi kebutuhan perusahaan karena perusahaan menginginkan adanya informasi yang akurat dan cepat (Sriwana et al., 2019).

Permasalahan pada inventory barang yang diteliti oleh penulis yakni pencatatan pengeluaran dan pemasukan barang yang dilakukan masih manual dengan masih menggunakan Microsoft Office yaitu menggunakan exel. Penggunaan Microsoft Office excel dalam mencatat pengeluaran dan pemasukan barang hal ini masih bersifat manual karena aplikasi tersebut tidak bisa menyimpan data dan informasi secara terpusat pada suatu basis data, sehingga sering kali terjadi ketidak sesuaian antara informasi yang didapat serta kehilangan data yang disebabkan oleh human error (Mufida et al., 2019). Pada proses persediaan dan pencatatan keluar masuk barang masih dilakukan secara manual pada buku dan Microsoft Excel sehingga sulit untuk mendapatkan informasi secara cepat (Azza \& Dores, 2018). Teknologi Sistem Informasi (TSI) masih mencatat pengajuan, pengadaan dan status pemasangan aset infrastruktur maupun software secara manual dengan menggunakan Microsoft Excel, selain itu pihak TSI dan user yang mengajukan tidak dapat memantau aset infrastruktur maupun software yang sedang diajukan (Ariastana \& Nurhidayat, 2018). Proses keluar masuk barang gudang pada PT. MUSASHI AUTO PARTS INDONESIA ditemukan banyak selisih stok barang ketika perhitungan akhir bulan (Fauzi et al., 2020).

Dengan permasalahan pada inventory barang ini maka memerlukan sebuah aplikasi menjadi terkomputerisasi sehingga pencatatan pengeluaran dan pemasukan barang berjalan dengan baik, informasi secara terpusat lebih efektif dan efisien serta informasi yang dihasilkan lebih tepat dan akurat. Dengan penerapan sistem informasi inventory barang berbasis web pada PT.Medan Smart Jaya dapat mempermudah inventory dan mempercepat proses penyampaian informasi persediaan barang (Yusrizal et al., 2020). Sistem informasi inventory atau persediaan yang akan memudahkan dalam pencatatan barang keluar dan masuk serta dalam pembuatan laporan persediaan barang untuk mempermudah dalam pengambilan keputusan (Wahyudiari, 2019).Dengan di bangun aplikasi sistem inventori gudang berbasis web pada PT. Alaisys dapat memberi solusi solusi dalam hak akses, pencatatan pengolahan data barang dapat meningkatkan efektifitas perusahaan (Religia \& Heriyanto, 2019). Dalam menganalisis dan merancang sistem ini pada Rehat Kopi 32 menggunakan model waterfall, dengan perancangan dan desain sistem inventory yaitu dengan menggunakan UML(Putri \& Wijoyo, 2020). Membangun sistem informasi inventory pada PT. Umbul Rejeki menggunakan model Waterfall dan UML sebagai tools dalam tahap perancangan membangun sistem informasi (Manalu \& Akmaludin, 2019). Metode penelitian yang digunakan pada Palang Merah Indonesia (PMI) kota Magelang menggunakan model Waterfall, dan perancangan Sistem menggunakan tools desain UML (Santoso et al., 2018). Dalam menganalisa dan merancang sistem ini pada Asia Group Pangkalpinang menggunakan model waterfall yang berorientasi objek dan berbasis web, dengan perancangan Sistem menggunakan tools desain UML (Hengki \& Suprawiro, 2017)

\section{METODE PENELITIAN}

Dalam proses perancangan sistem informasi ini penulis menggunakan Sistem Development Live Cycle (SDLC) dengan metode waterfall dimana pada metode ini dalam pembuatan sistem dilakukan secara teratur disetiap langkahnya dan terukur. Model Sistem Development Live Cycle (SDLC) air terjun (waterfall) sering juga disebut model sekuensial linier (sequential linear) atau alur hidup klasik (classic life cycle) (Fauzi et al., 2020). 
Indonesian Journal on Software Engineering (IJSE)

Vol. 7, No. 1, Juni 2021, hlm. 93-99

p-ISSN: 2461-0690

Akreditasi KEMENRISTEKDIKTI, No. 85/M/KPT/2020

e-ISSN: 2714-9935 2020):

Dalam pengembangannya metode waterfall memiliki lima tahapan sebagai berikut (Sanubari et al.,

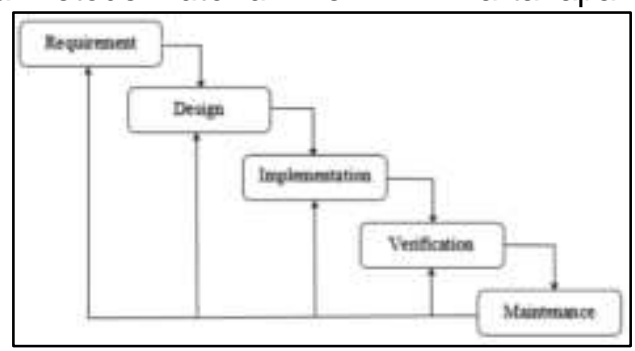

Gambar 1. Pemodelan Waterfall

Pada gambar 1 menunjukan proses dari awal sampai akhir tahapan yang dilakukan dalam pengembangan sistem informasi yakni Analisis Kebutuhan (Requirement), disain sistem (Design), Implementasi (Implementation), verifikasi atau pemeriksaan (Verification) dan pemeliharaan (Maintenance).

1. Requirement

Dalam tahap ini penulis melakukan analisis mendalam tahapan sistem yang sedang berjalan, sehingga penulis bisa melihat kebutuhan dengan baik proses yang terjadi. Sehingga akan mempermudah penulis didalam membuat sistem informasi persediaan barang.

2. Design

Desain yang digunakan dalam sistem informasi persediaan barang penulis menggunakan tools desain United Modelling language (UML), sedangankan dalam perancangan database menggunakan tools desain Logical Record Structure (LRS)

3. Implementation

Pada perancangan program ini penulis membuat pemograman dengan menggunakan bahasa pemrograman Personal Home Page (PHP), Hyper Text Markup Language (HTML), Cascading Style Sheets (CSS), JavaScript dengan framework Codeigniter serta database MySQLi

4. Verification

Pengujian aplikasi dilakukan untuk memastikan bahwa aplikasi yang dibuat telah sesuai dengan desain dan semua fungsi dapat berjalan dengan baik tanpa ada kesalahan, yakni dengan pengujian dilakukan dengan metode black-box testing.

5. Maintenance

Pada tahapan ini penulis melakukan beberapa hal yang dapat mendukung agar apllikasi yang telah dibuat dapat digunakan secara maksimal yaitu dengan cara mendokumentasikan semua informasi dan melakukan pemeliharaan terhadap aplikasi yang telah dibuat.

\section{HASIL DAN PEMBAHASAN}

Untuk memudahkan penulis membuat sistem dengan membutuhkan beberapa rancangan meliputi pembuatan desain dan rancangan sistem dengan diagram Unifed Modelling Language (UML), sedangkan untuk pembangunan software yang dibuat dengan object-oriented programming (OOP).

\subsection{Planning}

Sistem informasi inventory barang membutuhkan peran dimana petugas gudang sebagai administrator untuk mengelola data supplier, data kategori, data produk, barang masuk, data pesanan atau barang keluar, laporan barang masuk, laporan data pesanan, laporan supplier dan laporan produk. 
Indonesian Journal on Software Engineering (IJSE)

Vol. 7, No. 1, Juni 2021, hlm. 93-99

p-ISSN: 2461-0690

Akreditasi KEMENRISTEKDIKTI, No. 85/M/KPT/2020

e-ISSN: 2714-9935

\subsection{Desain}

Tools desain yang digunakan dalam merancang database menggunakan Logical Record Structure (LRS) yakni pada aplikasi Sistem informasi inventory barang sebagai beikut:

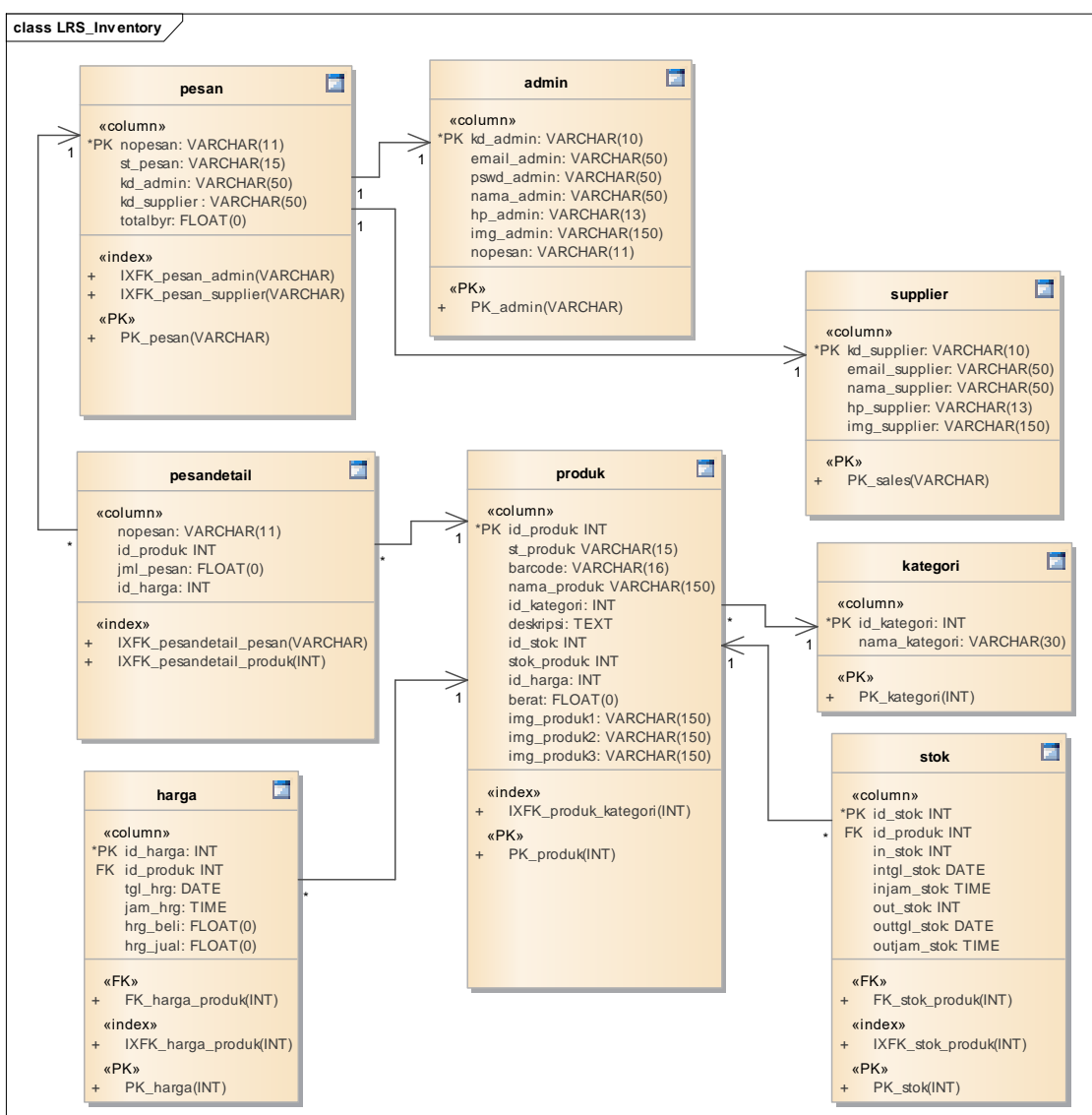

Gambar 2. Logical Record Structure (LRS) aplikasi Sistem informasi inventory

Pada gambar 2, terlihat dengan jelas bagamana relasi database yang dibangun pada aplikasi Sistem informasi inventory yang terdiri data 8 tabel yang saling ber-relasi yaitu tabel pesan dan pesandetail sebagai data transaksi barang keluar, tabel admin yang bertugas sebagai petugas gudang, tabel supplier sebagai data pelanggan, tabel produk sebagai data master yang ber-relasi dengan tabel harga, kategori dan stok.

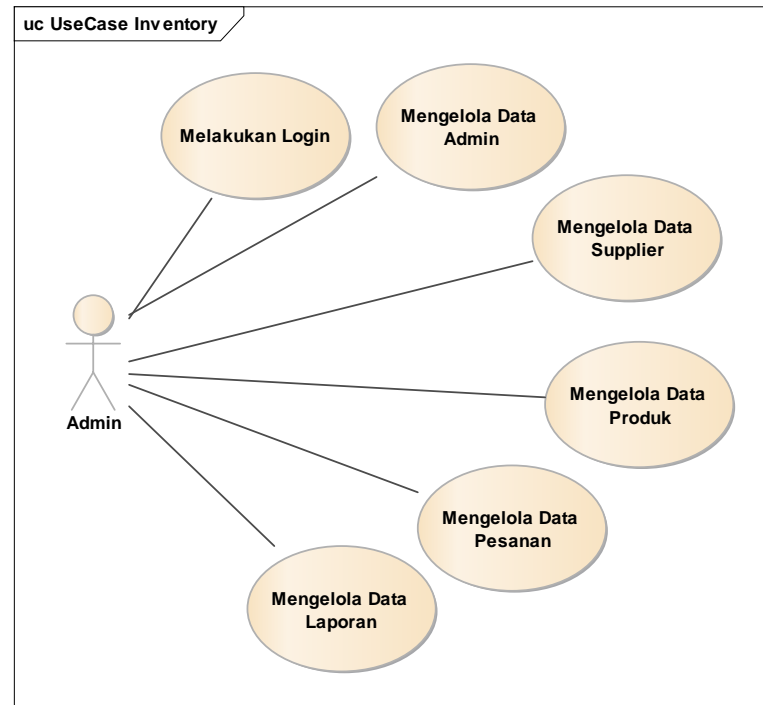

Gambar 3. Use Case Diagram Aplikasi Sistem informasi inventory 
Indonesian Journal on Software Engineering (IJSE)

Vol. 7, No. 1, Juni 2021, hlm. 93-99

p-ISSN: 2461-0690

Akreditasi KEMENRISTEKDIKTI, No. 85/M/KPT/2020

e-ISSN: 2714-9935

Pada gambar 3 diatas terdapat 1 (satu) aktor, dimana aktor tersebut adalah admin atau administrator. Pada aktor admin menggambarkan user sebagai petugas gudang secara sepenuhnya untuk mengelola aplikasi tersebut, baik mengelola data master yakni data admin atau petugas gudang, data supplier, data kategori, data produk, sedangkan data transaksi yakni data pesanan atau barang keluar, kemudian mengelola data laporan seperti laporan supplier atau pelanggan, produk, barang masuk dan pesanan.

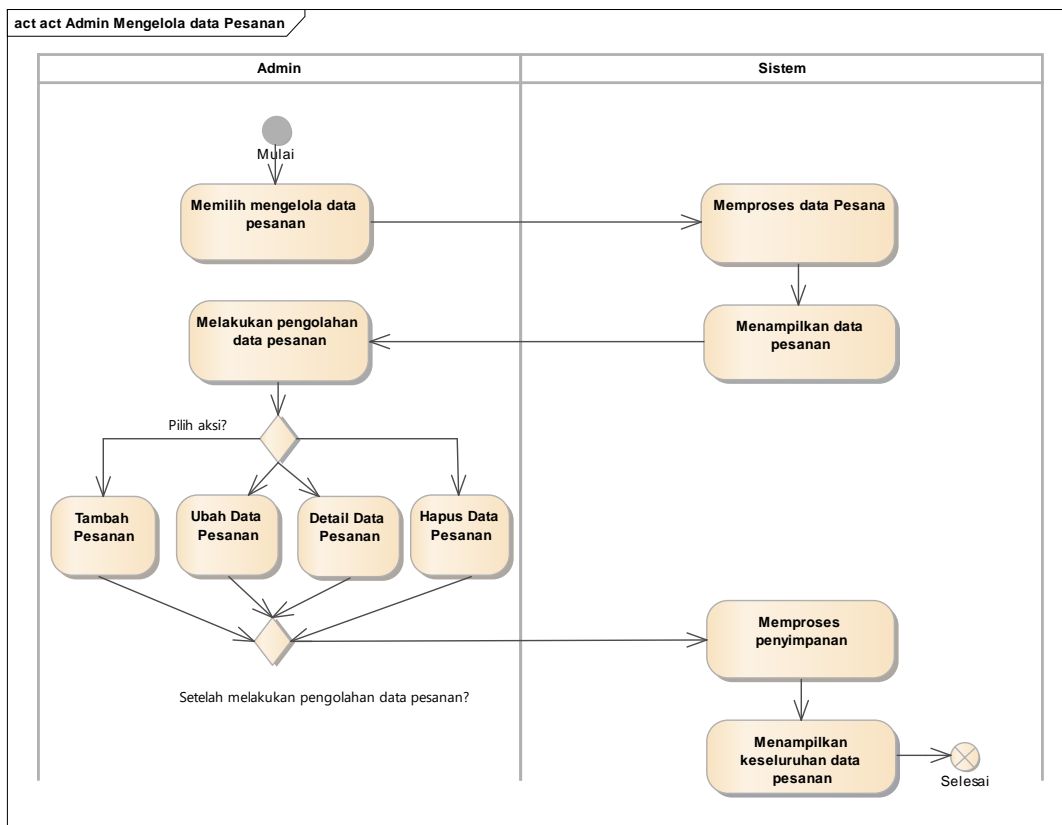

Gambar 4. Activity Diagram Mengelola Data Pemesanan

Gambar 4 menunjukan Activity Diagram mengelola data pemesanan bagaimana proses mengelola data pemesanan yaitu pesanan barang pada aplikasi sistem informasi inventory dimana terdapat aksi bisa menambah, mengubah, detail dan menghapus pesanan yang dilakukan oleh petugas gudang sesuai dengan pesanan supplier.

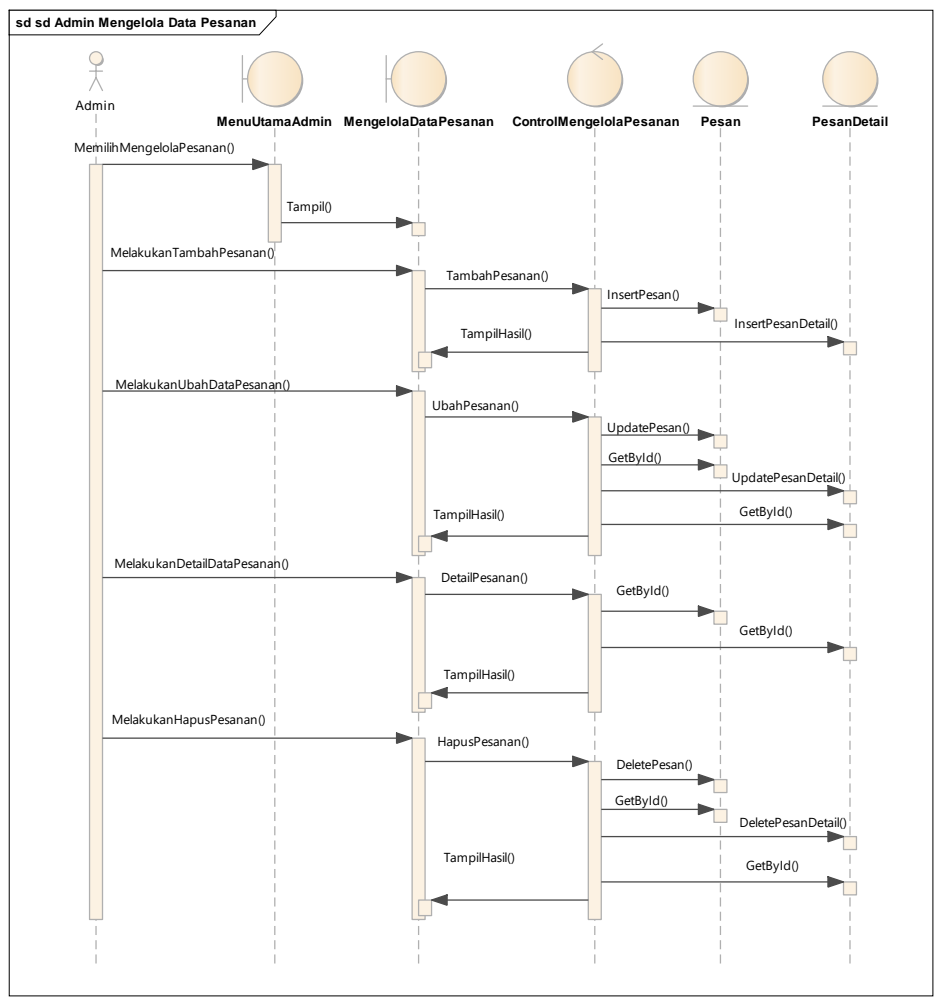

Gambar 5. sequence Diagram Mengelola Data Pemesanan 
Indonesian Journal on Software Engineering (IJSE)

Vol. 7, No. 1, Juni 2021, hlm. 93-99

p-ISSN: 2461-0690

Akreditasi KEMENRISTEKDIKTI, No. 85/M/KPT/2020

e-ISSN: 2714-9935

Gambar 5 menunjukan sequence Diagram Mengelola Data Pemesanan bagaimana proses mengelola data pemesanan yaitu pesanan barang pada aplikasi sistem informasi inventory dimana terdapat aksi tamba, ubah, detail dan hapus pesanan dengan menggunakan controller pesanan tabel pesan dan detailpesan. Dimana pada tabel pesan ber-relasi dengan tabel admin dan supplier sedangkan detailpesan ber-relasi dengan produk, dimana hal ini sesuai dengan rancangan pada Logical Record Structure (LRS).

\subsection{User Interface}

Pada saat aplikasi sistem informasi inventory barang diakses maka sistem akan menampilkan halaman halaman login:

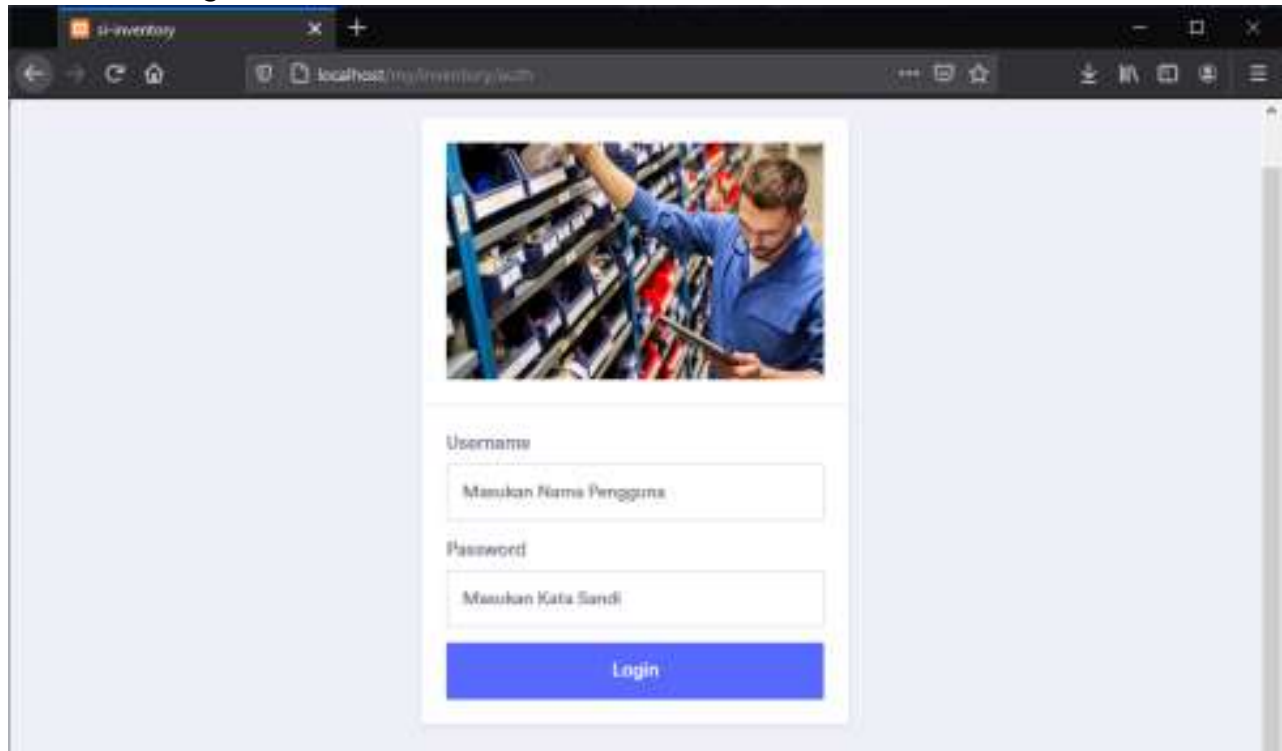

Gambar 6 Halaman Login Administaror

Halaman login administaror ini diperuntukan bagi user yang telah diberi hak ases khususnya petugas gudang sebagai admin atau administaror. Dengan memasukan username dan password halaman login administaror, jika berhasil login maka akan masuk pada halaman utama administaror, namun jika tidak berhasil tetap pada halaman login administaror.

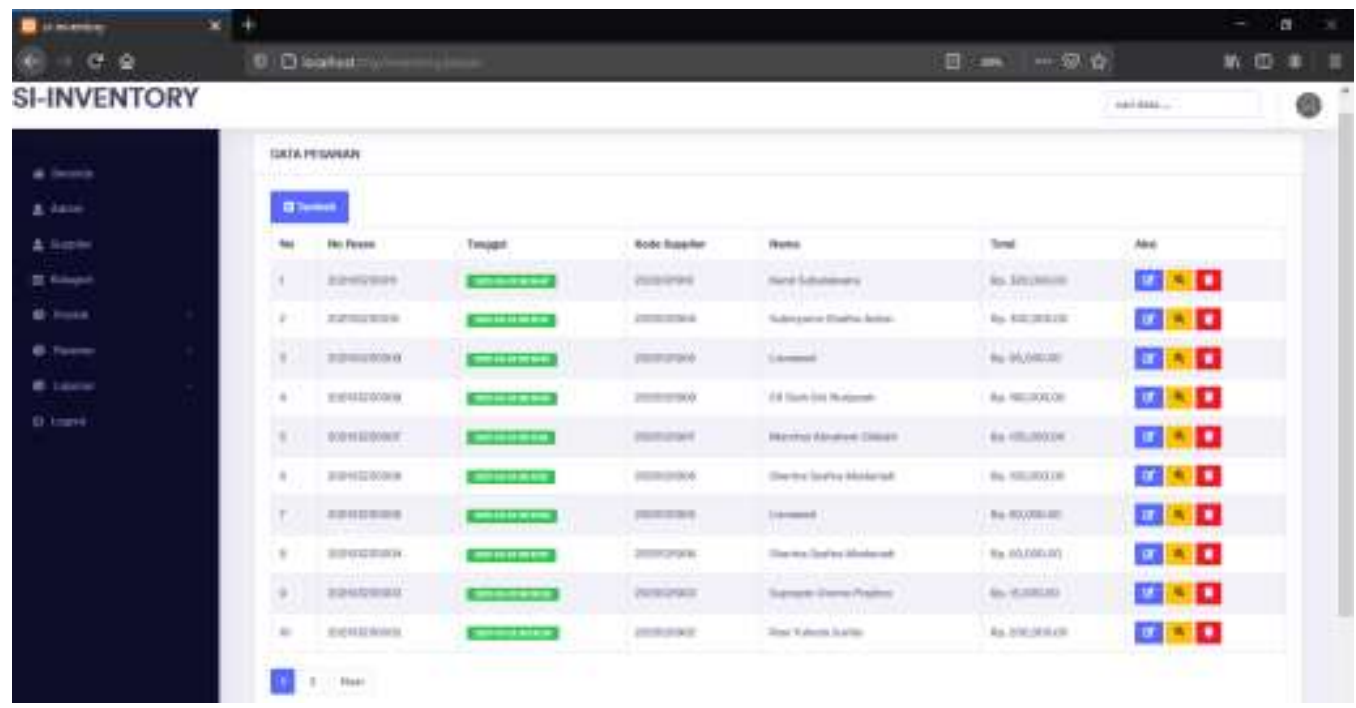

Gambar 7. Halaman Mengelola Data Pemesanan

Gambar 7 ini adalah hasil dari aplikasi sistem informasi inventory yakni pada halaman mengelola data pemesanan dimana tampilan ini sesuai dengan rancangan aplikasi sistem inventory barang dengan menggunakan tools desain United Modelling language (UML) dengan rancangan pada Use Case Diagram, Activity Diagram dan sequence Diagram. Dimana pada halaman ini terdapat aksi tambah, ubah, detail dan hapus. Dengan menampilkan sekilas data pemesanan pada filed nomor pesan, tanggal pesan, kode supplier, nama supplier dan total bayar. 


\section{KESIMPULAN}

Proses pencatatan inventory yang dilakukan secara manual atau konvensional banyaknya menimbulkan masalah seperti ketidak sesuaian antara informasi yang didapat serta kehilangan data yang disebabkan oleh human error atau banyak selisih stok barang yang terjadi, lambatnya dalam mengambil keputusan dan sulitnya pada saat pembuatan laporan. Dengan demikian memerlukan sebuah aplikasi menjadi terkomputerisasi sehingga pencatatan pengeluaran dan pemasukan barang berjalan dengan baik. Menganalisis dan merancang suatu sistem aplikasi diperlunya suatu metode, dalam hal ini penulis menggunakan model waterfall berorientasi objek dengan melakukan perancangan sistem menggunakan tools desain UML dengan perancangan dan tools desain LRS menjadi lebih dipermudahkan dalam melakukan perancangan sistem dan dikemudian hari untuk dilakuakn pengembangan lebih lanjut dengan melihat tahapan-tahapan yang harus dilakukan.

\section{REFERENSI}

Ariastana, N. M. A. R. L., \& Nurhidayat, A. I. (2018). Rancang Bangun Aplikasi Manajemen Aset Infrastruktur Dan Lisensi Software Menggunakan Framework Laravel (Studi Kasus: Perusahaan Daerah Air Minum Surya Sembada Kota Surabaya). Jurnal Manajemen Informatika, 8(2), 68-74.

Azza, G. M., \& Dores, A. (2018). Sistem Informasi Manajemen Marketing Tools Serta Penerapan Metode Ahp (Analytical Hierarchy Process) Pada Proses Uji Kualitas Barang (Studi Kasus: PT Edi Indonesia). Jurnal Cendikia, XVI, 107-114.

Fauzi, A., Indriyani, N., \& Yanto, A. B. H. (2020). Sistem Informasi Inventory Barang Berbasis Web Dengan Menggunakan Metode Waterfall Pada PT. Musashi Auto Parts Indonesia. SIGMA - Jurnal Teknologi Pelita Bangsa, 3(2622-1659).

Hengki, H., \& Suprawiro, S. (2017). Analisis dan Perancangan Sistem Informasi Inventory Sparepart Kapal Berbasis Web Studi Kasus Asia Group Pangkalpinang. Jurnal SISFOKOM, 06(September), 121129.

Manalu, I. M., \& Akmaludin, A. (2019). Perancangan Sistem Informasi Inventory Pada Gudang Consumable Pada Pt. Umbul Rejeki Cikarang. INTI Nusa Mandiri, 13(2), 21-26.

Mufida, E., Rahmawati, E., \& Hertiana, H. (2019). Rancang Bangun Sistem Informasi Inventory Pada Salonkecantikan. Jurnal Mantik Penusa Vol.3, No.3 Desember 2019, Pp 99-102, 3(3), 99-102. http://e-jurnal.pelitanusantara.ac.id/index.php/mantik/article/download/671/409

Nugraha, W., Syarif, M., \& Dharmawan, W. S. (2018). Penerapan Metode Sdlc Waterfall Dalam Sistem Informasi Inventori Barang Berbasis Desktop. JUSIM (Jurnal Sistem Informasi Musirawas), 3(1), 22 28. https://doi.org/10.32767/jusim.v3i1.246

Putri, A. S., \& Wijoyo, A. (2020). Perancangan Sistem Inventori Barang Pada Rehat Kopi 32 Berbasis Web. JOURNAL OF ARTIFICIAL INTELLIGENCE AND INNOVATIVE APPLICATIONS, 1(4), 177-183.

Religia, Y., \& Heriyanto, H. (2019). Sistem Informasi Inventory Barang Berbasis Web Dengan Menggunakan Metode Waterfall Pada PT. Musashi Auto Parts Indonesia. SIGMA Information Technology Journal, 10. https://doi.org/10.26740/jieet.v1n1.p40-46

Santoso, K. I., Sundari, C., \& Kristiani, A. F. (2018). Sistem Informasi Persediaan Darah Berbasis Web Studi Kasus Di PMI Kota Magelang. Jurnal Transformasi, 14(1), 92-100.

Sanubari, T., Prianto, C., \& Riza, N. (2020). Odol (one desa one product unggulan online) penerapan metode Naive Bayes pada pengembangan aplikasi e-commerce menggunakan Codeigniter. Kreatif. https://www.google.co.id/books/edition/Odol_one_desa_one_product_unggulan_onlin/s4j_DwAAQ BAJ?hl=id\&gbpv $=1$

Sriwana, I. K., Christia, M. L., Ellytasia, E., \& Chandiawan, G. (2019). Perancangan Sistem Informasi Inventory Pt. Abc. Jurnal Ilmiah Teknik Industri, 6(1), 9-19. https://doi.org/10.24912/jitiuntar.v6i1.3019

Vikaliana, R., Sofian, Y., Solihati, N., Adji, D. B., \& Maulia, S. S. (2020). Manajemen Persediaan. MEDIA SAINS

https://www.google.co.id/books/edition/Manajemen_Persediaan/hLgKEAAAQBAJ?hl=id\&gbpv=1

Wahyudiari, N. L. D. E. (2019). Sistem Informasi Inventory Berbasis Web Pada CV Bali Batik. Infotech, 5, 38-43.

Yusrizal, T., Hasugian, B. S., \& Yasir, A. (2020). SISTEM INFORMASI INVENTORY BARANG PADA PT . MEDAN SMART JAYA BERBASIS WEB. Journal Of Information System, Computer Science And Information Technology, 1(2), 45-58. 